\title{
Doctors mobilize against tax changes
}

\author{
Cite as: CMAJ 2017 September 5;189:E1121-2. doi: 10.1503/cmaj.1095475
}

Posted on cmajnews.com on Aug. 15, 2017, updated on Aug. 23, 2017.

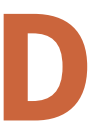
octors, accountants and lawyers are uniting to oppose tax changes they say will undercut physicians' financial security and make Canada a less attractive place to practise.

The federal government is consulting stakeholders on reforms to prevent highearning professionals from reducing their taxes by holding investments in corporations and diverting income to family members in lower tax brackets. Finance Minister Bill Morneau told reporters the current rules were intended to support small businesses, but wealthy people increasingly exploit them as part of "fancy accounting schemes."

"This isn't about a business not paying its fair share," he said. "It's about people using a corporate structure to shield their income and gain a tax advantage."

Doctors say they rely on the tax benefits of incorporating to offset the risks and expenses of self-employment. The proposed reforms ignore that most physicians are small business people, says John Feeley, vice-president of member relevance at the Canadian Medical Association (CMA). Unlike salaried employees, doctors don't have pension plans, paid parental leave, mandatory vacation, sick leave or disability benefits. Taxing them at the same rates "just doesn't make sense," Feeley says. "It's apples and oranges."

CMA warns that changing the rules will cause "severe instability in the health sector" and may end up "driving away highly skilled professionals." The organization is still developing a formal response to the government's proposals and sought input from members at its general council and annual meeting in Quebec City on Aug. 20-23, 2017. Provincial physician groups are organizing similar responses. The Ontario Medical Association has been the most vocal, launching a social media campaign and provincial petition, and blasting the reforms in newspaper columns.

Ontario doctors won the right to incorporate more than 15 years ago in lieu of fee increases, notes Nicky Huq, a corporate lawyer based in Toronto. "It's really disingenuous for the federal government to say they're using a loophole for the wealthy when this was a negotiated form of compensation." to doctors who are the primary providers for their families, those in earlier stages of their careers, and those running "capital intensive" or rural medical practices.

The government anticipates it will recoup an extra $\$ 250$ million annually by curtailing income "sprinkling" - that is, when a high-earner uses a corporation to divert some of their income to family members who are taxed at lower rates, or

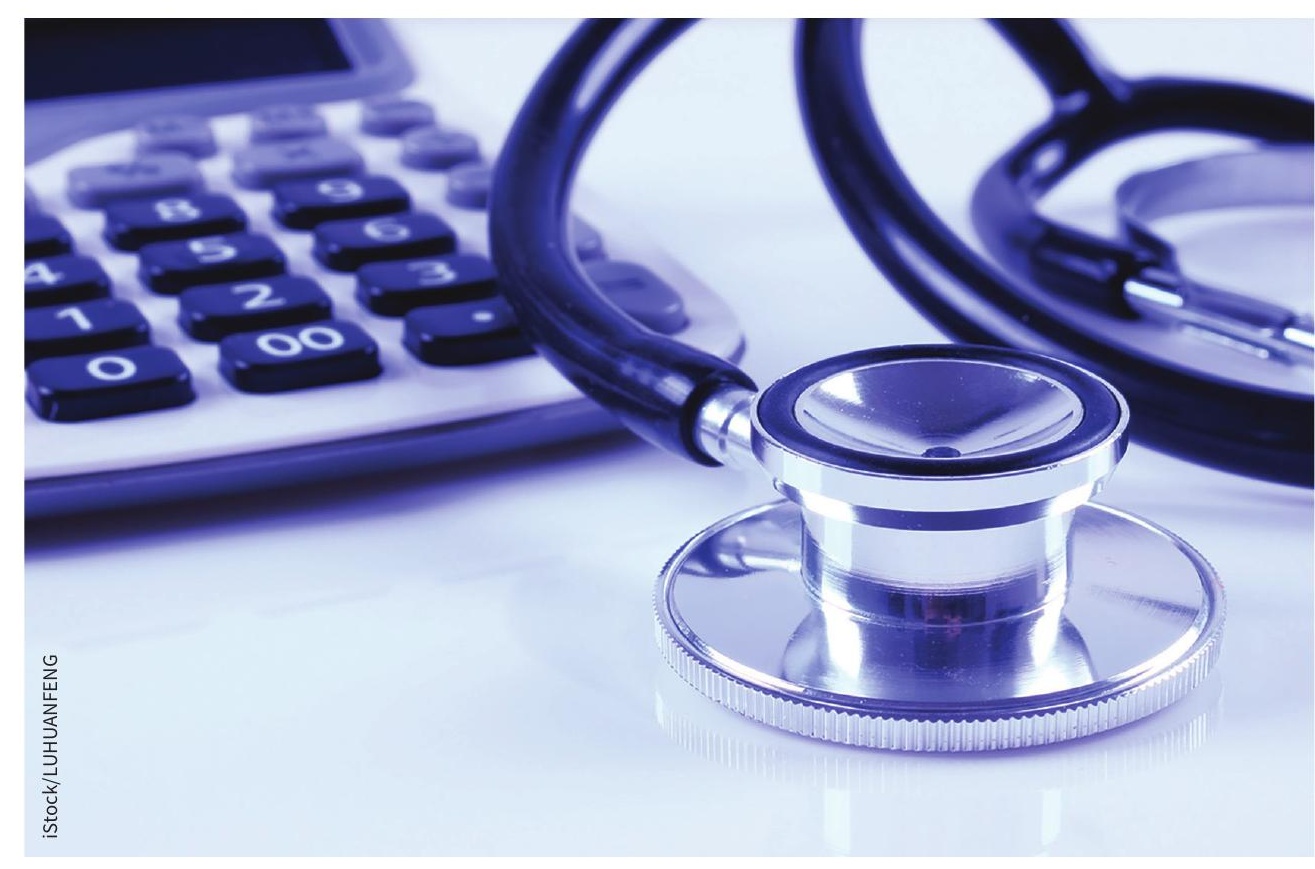

The Canadian Medical Association says proposed tax reforms will have unfair and serious impacts on most doctors.

Huq is coordinating a response by accountants and lawyers to explain why the reforms are "misguided." She expects to rally more than 75 firms, each representing hundreds of physician clients. "We see the financial realities of their situation and I think have a more unbiased perspective."

\section{Who will be affected?}

Physician tax specialists say the proposed changes will deal the heaviest blow who may not be taxed at all. Morneau plans to impose a "reasonableness" test to determine whether those family members contribute enough to a business to lay claim to profits.

The impact on physicians will be "quite significant," particularly for toppaid specialists who are the sole breadwinners for their families, says Elliott Stone, founder of MD Tax Physician Services in Toronto. "That would probably be 
the most extreme example of someone who would be most affected, because each family member they could split income with is probably $\$ 10000$ to $\$ 15000$ of tax savings."

It's harder to calculate the potential fallout of the government's proposal to "neutralize" the tax advantages of holding an investment inside a corporation, Stone said. A person can be taxed as much as $53 \%$ on income they take out of a corporation, compared to rates as low as $15 \%$ if they hold the money in an investment portfolio inside the company.

Some doctors use this strategy as it was intended to grow funds to expand their practices, says Aly Khan Musani, a partner at MMT Chartered Professional Accountants in Calgary. "If they happen to park those funds in an investment in the interim and you're penalizing them for that, you're not really considering their long-term intent."

Many doctors also rely on this strategy as a kind of "pension plan," explains Brad Bokhaut, a Winnipeg-based accountant for more than 1000 physicians. "They have funded their retirement by accumulating enough money in their corporation to pay out a given dividend to each spouse in retirement, to provide a given amount of after-tax funds each year."

The government won't apply the proposed reforms retroactively to investments physicians have already accumulated inside their corporations, says Bokhaut. However, "it could have more impact on those now accumulating investments."

Stone says, "it's really the young physicians and those in the middle of their careers who will be most affected." He predicts radiologists, plastic surgeons and other specialists running clinics with "huge capital outlays" will face the greatest setbacks. Rural family doctors may struggle, too, with less buffer for "all of the overhead" associated with their practices.

There may also be "a bunch of unintended consequences" that will only be realized once accountants get down to the "nitty-gritty of preparing a tax return," Stone adds.

Even so, Musani cautions that "people shouldn't start making radical changes to their portfolios or bringing money out of their corporations." Until the government's consultation closes on Oct. 2, doctors and other professionals should focus on advocacy, he says. "Get as many people to respond to this as possible because it's your opportunity to be heard."

Lauren Vogel, CMAJ 